\title{
Some Greek Inscriptions from Caria and Phrygia
}

\author{
Esengül AKINCI ÖZTÜRK*
}

In this article six inscriptions are discussed. One of them (no. 1) was found at Beçin Kalesi near Mylasa in Caria, while nos. 2, 3, 5, 6 were discovered by Prof. B. Söğüt during his survey in Acıpayam Ovası (Kazanes Valley) in Phrygia, in 2003. ${ }^{1}$

\section{List of Names}

Mylasa. Piece of a marble block. The stone was unearthed during the excavations at Beçin near Mylasa. ${ }^{2}$ It is now preserved in the Milas Museum. Height $0.21 \mathrm{~m}$; width $0.20 \mathrm{~m}$; thickness $0.20 \mathrm{~m}$; height of the letters $0.007 \mathrm{~m}$.

\section{[?]}

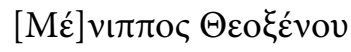

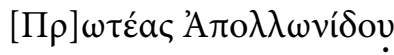

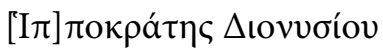

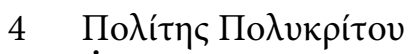

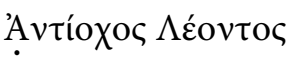

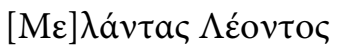

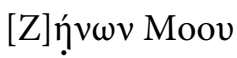

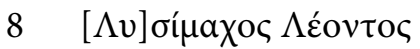

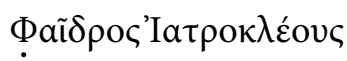

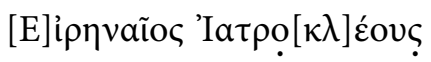

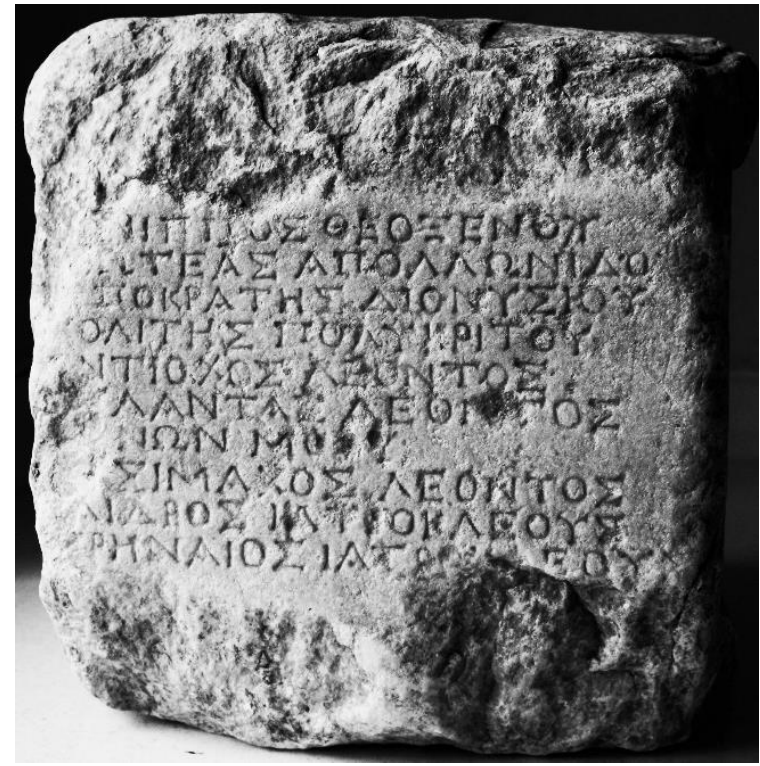

Menippos, son of Theoxenos, Proteas, son of Apollonides, Hippokrates, son of Dionysios, Polites, son of Polykritos, Antiochos, son of Leon, Melantas, son of Leon, Zenon, son of Moas, Lysimachos, son of Leon, Phaidros, son of Iatrokles, Eirenaios, son of Iatrokles.

Lines 5-6, 8 and 9-10: The persons with homonymous patronymics (i.e. Leon and Iatrokles) were perhaps brothers.

* Dr. Öğretim Üyesi Esengül Akıncı Öztürk, Pamukkale Üniversitesi, Fen-Edebiyat Fakültesi, Arkeoloji Bölümü, Denizli (eakinci@pau.edu.tr).

I am grateful to Professor Hasan Malay for his kind help during the preparation of this article.

${ }^{1}$ For some of the inscriptions copied during this research see Akıncı Öztürk - Malay 2012, 89-92 (SEG 62, 1148-1151).

${ }^{2}$ For an announcement of this discovery see Pektass 2013, p. 319. It is a pleasure to thank Professor Kadir Pektaş, Director of the Excavations at Beçin Kalesi, for his kind permission to publish this inscription. 
Line 7: On the indigenous name Moas, attested in Cilicia, Lycia, Pamphylia and possibly Pisidia, see Helly 2010, p. 96, an overwiew of the attestations of the name (= SEG 60, 592); Zgusta 1964, § 940-1, referred to by Horsley 2007, no. 79, cf. also LGPN V.B. s.v.

The names in the list may have belonged to eponymous magistrates or priests. It is difficult to judge whether the text is complete or some lines above were later erased.

Date: Hellenistic Period

\section{Funerary Inscription for Menis}

Yeşilyuva (Keretapa Diokaisareia). ${ }^{3}$ Funerary column of marble. A channel was hollowed out from top to bottom so that the edges of all the lines have been destroyed. The stone is currently in the garden of the former municipality of Yeşilyuva NE of Acıpayam. Height 0.94 m; diam. 0.42 m; letters between 0.02 and $0.025 \mathrm{~m}$. In line $3 \mathrm{~m}$, the letters $\mathrm{MH}$ are ligatured.
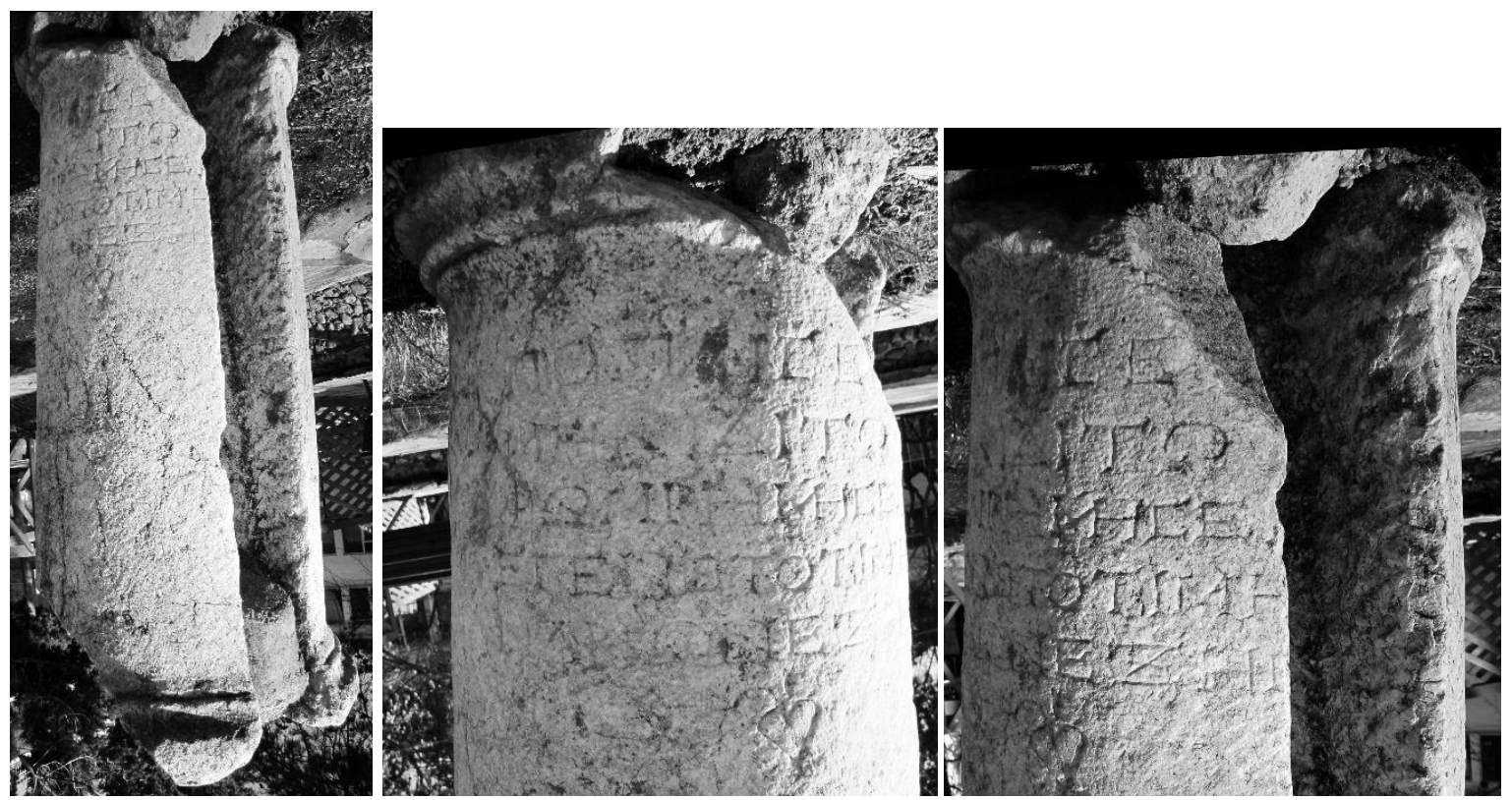

Пó $\pi \lambda_{\iota \varsigma} \mathrm{E}[\mathrm{]}$

Mńvı $\delta \iota \tau \tilde{\omega}[a ̉ \delta \varepsilon \lambda]-$

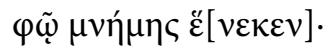

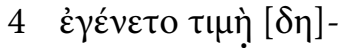

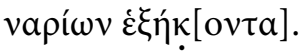

"Poplis, son of E..., (set this up) for his brother Menis, in memory. An honorific statue was executed for the price of 60 denarii".

Line 4: $\tau \iota \mu$ should have the meaning of "honorific statue" (see Herrmann 1993, 254, n. 74). This means that the column probably supported a statue depicting the deceased.

Date: Roman Imperial Period

${ }^{3}$ For Keretapa Diokaisareia see Robert 1962, 105-121 and 318-338, cf also Leschhorn 1993, 287-288 and Milner 1998, p. 53 with doubts about its location at Yeşilyuva. 


\section{Dedication by Proteas, son of Monios}

Acıpayam Ovası (Kazanes Valley). Limestone altar with mouldings above and below. It is at present in the depot of Acıpayam Municipality. The inscription with too careless script is engraved above the altar. On the main field below the inscription is the figure of an unidentified animal facing towards right where perhaps the remnants of a sitting figure are. On the back side of the altar is depicted a radiate head of the recipient god (Helios ? Hosios and Dikaios ?). Height $0.87 \mathrm{~m}$; width $0.40 \mathrm{~m}$; thickness $0.30 \mathrm{~m}$; letters varying between 0.028 and $0.03 \mathrm{~m}$.
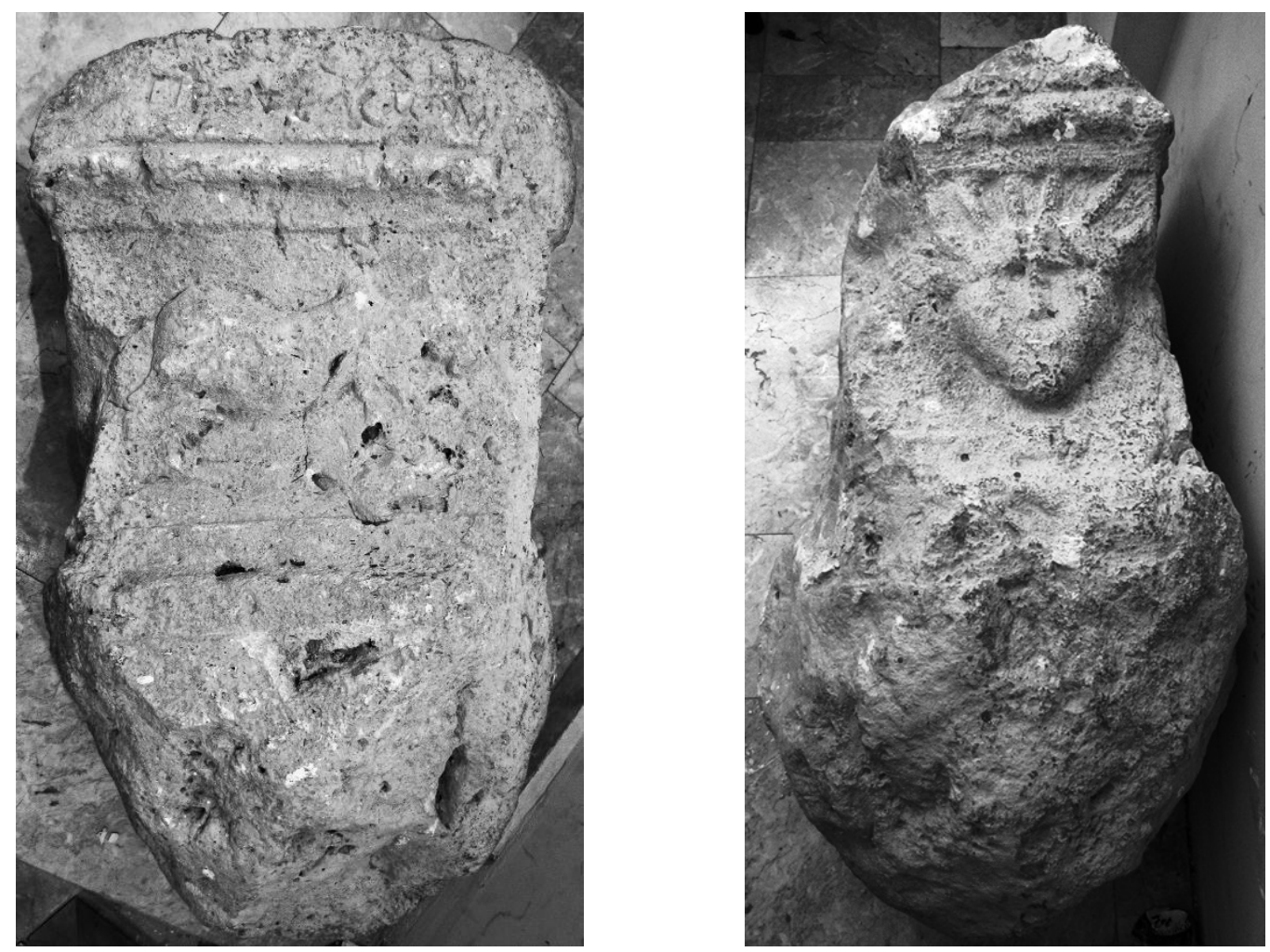

[?] عủxì

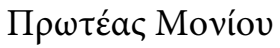

"Proteas, son of Monios, made a vow".

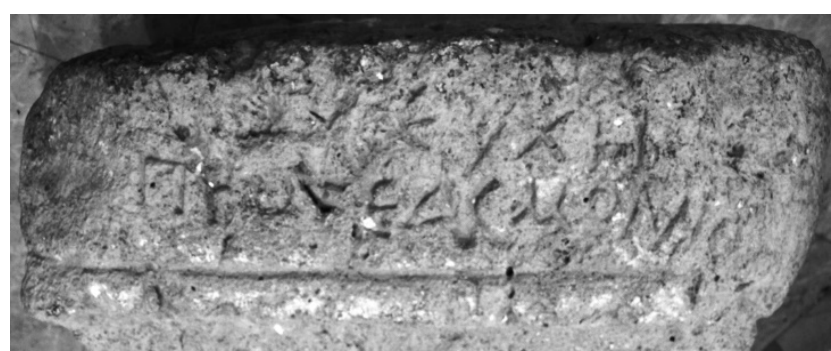

Line 1: It is not clear whether the left part of the line, where one would expect the name of the recipient god(dess), was later erased, or, because of some damages on the surface, was left free. - There

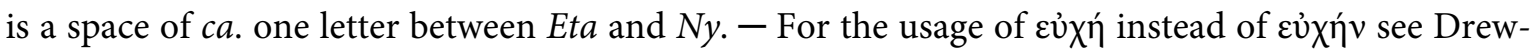
Bear 1976, p. 253.

Line 2: The name Movíoc is very rare; the only parallel known to us is from Crete: LGPN I, s.v. (Gortyn).

Date: Roman Imperial Period 


\section{Funerary Imprecation Mentioning the "Enraged Gods" of Pisidia}

(Strubbe, Arai Epitymbioi, 130, rediscovered)

Yeşildere (Eriza). ${ }^{4}$ Marble block which is used for supporting a wooden column of a house in the

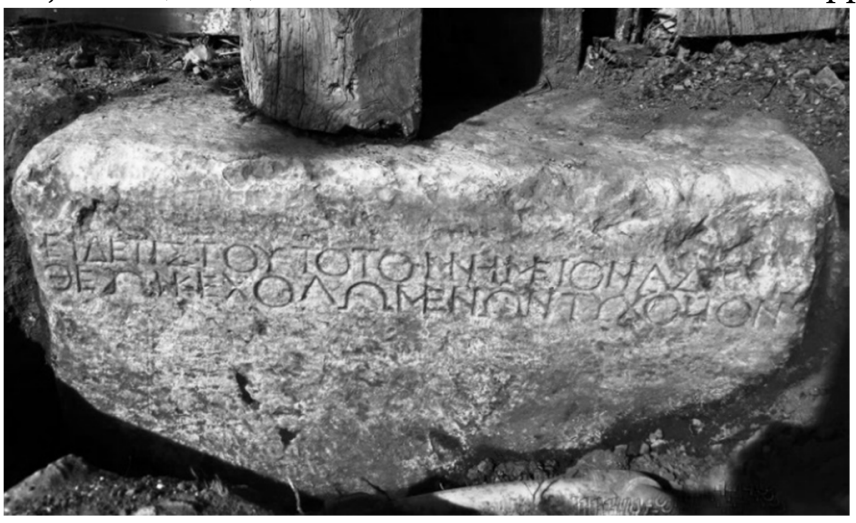
village of Yeşildere, formerly Dereköy. Regarding the identical wording, the ligatured letters, the damage on the right upper corner of the surface, and the find-spot, it must be identical as Strubbe's no. 130 which was discovered by G. Cousin who describes the find-spot: "Grande pierre carrée servant de base à un pilier en bois". ${ }^{5}$ Height $0.45 \mathrm{~m}$; width $0.67 \mathrm{~m}$; thickness $0.65 \mathrm{~m}$; letters $0.02 \mathrm{~m}$.

On the damaged part of the surface Cousin read ả $\delta[\iota \kappa \eta ́] \sigma \eta ̣$ but today only the lower half of Sigma is visible while the last Eta is totally lost.

For recent discoveries of funerary curses from the Acıpayam (Kazanes) Plain see Akıncı ÖztürkMalay, op. cit. supra note 1.

Date: Roman Imperial Period

\section{Funerary Inscription for Zosimos}

Ören Mevkii, between Dodurga and Yazır, S of Eriza (cf. the next item from the same spot). ${ }^{6}$ Funerary column of marble with mouldings above and below. Now it is in the garden of the former municipality of Dodurgalar. Height $1.27 \mathrm{~m}$, diam. $0.35 \mathrm{~m}$ (above) and $0.44 \mathrm{~m}$ (below); letters varying between 0025 and $0.04 \mathrm{~m}$. Ligaturae in lines $2(\mathrm{NT}), 3(\omega \mathrm{NMHN}), 5(\mathrm{MHN}), 6(\mathrm{MNH})$.
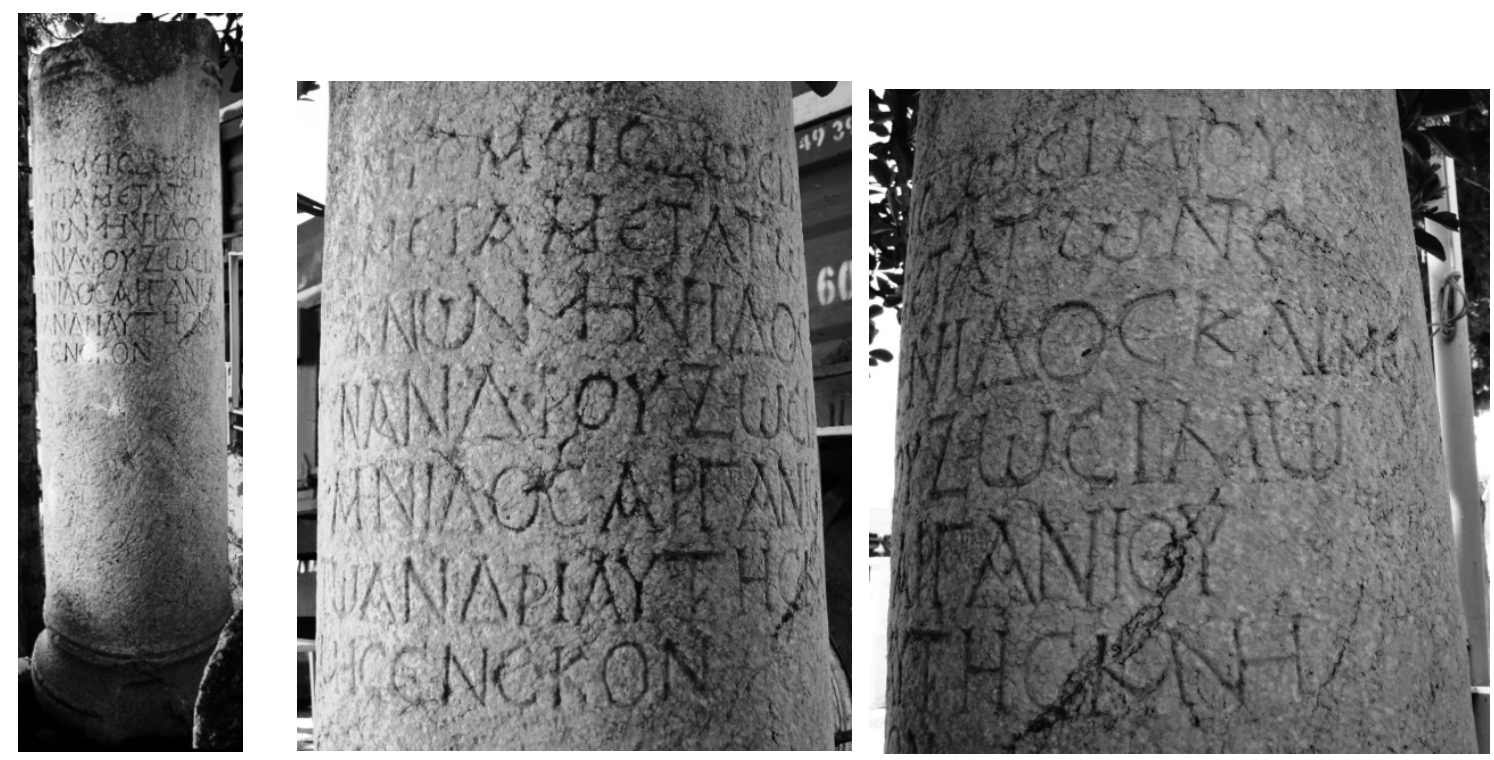

\footnotetext{
${ }^{4}$ For the possible location of Eriza see Akıncı Öztürk - Malay 2012, p. 89, note 3 with bibliography.

${ }^{5}$ Cousin 1900, 54-55.

${ }^{6}$ For four inscriptions from Ören Mevkii see Akıncı Öztürk - Malay, op. cit.
} 


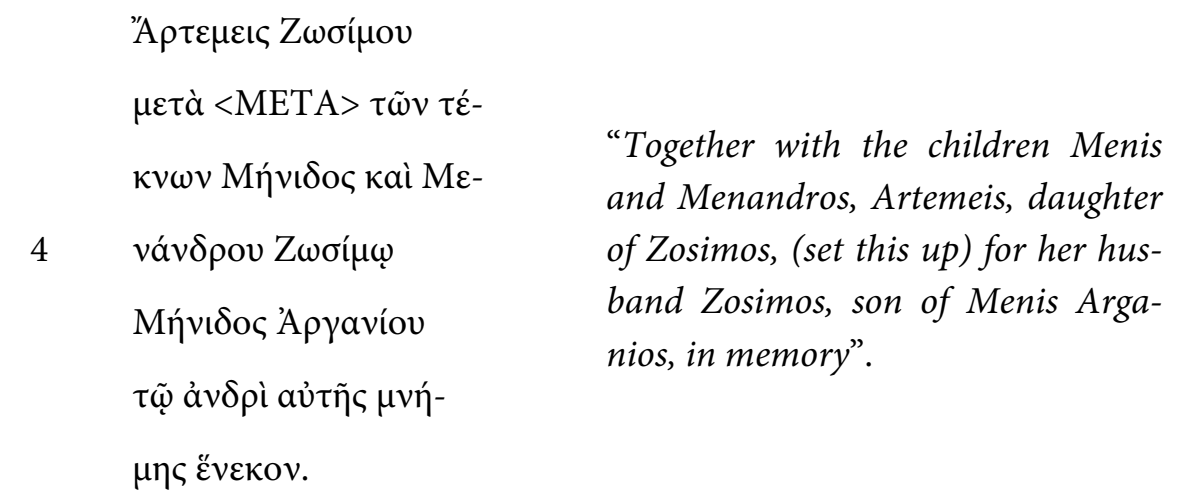

Line 2: METAMETA lapis by dittography.

Line 5: The name Apүávıoc, here appearing as the second name of the father of the deceased, seems to be a patronymic adjective from "A $\rho \gamma a v o \varsigma$ which occurs twice in a list of Cretans as new citizens of

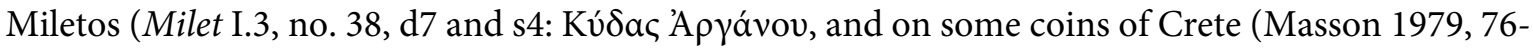
8 [= SEG 29, 827 and LGPN I, s.v.]).

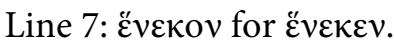

Date: Roman Imperial Period

\section{Funerary Inscription for Artemeisia}

Ören Mevkii, between Dodurga and Yazır, S of Eriza (cf. the preceding inscription from the same spot). Marble funerary column with mouldings above and below. This column is now kept in the garden of Sağlık Ocağı at Dodurga. Height $0.88 \mathrm{~m}$; diam. $0.33 \mathrm{~m}$; letters from 0.015 to $0.030 \mathrm{~m}$.

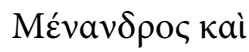

Mĩvıৎ 'A $\rho \tau \varepsilon-$

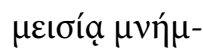

$4 \eta \varsigma \check{\varepsilon} \nu \varepsilon \kappa \varepsilon \nu$.

"Menandros and Menis (set this up) for Artemeisia, in memory".

The tomb was erected by two sons or brothers of Artemeisia. The relation of Menandros and Menis with the deceased is not specified (their mother or sister ?).

Date: Roman Imperial Period

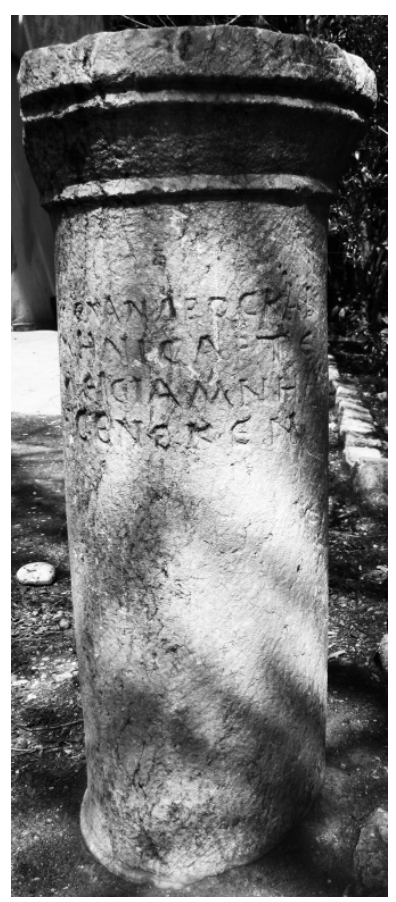




\section{Bibliography}

Akıncı Öztürk - Malay 2012 E. Akıncı Öztürk - H. Malay, Four Funerary Curses Recording the Pisidian Gods of the Acipayam Plain, EA 45, 2012, 89-92.

$\mathrm{BCH}$

Bulletin de Correspondance Hellénique

Cousin 1900

G. Cousin, Voyage en Carie, BCH 24, 1900, 24-69.

Drew-Bear 1976

Th. Drew-Bear, Local Cults in Graeco-Roman Phrygia, GRBS 17.3, 1976, 247-268.

EA

GRBS

Epigraphica Anatolica

Helly 2010

Herrmann 1993

Greek, Roman, and Byzantine Studies

B. Helly, Un concurrent originaire d'Antioche de Pisidie dans un catalogue de vainqueurs aux concours des Éleuthéria de Larisa (ENTRE 80 et 70 av. J.-C.), ZPE 172, 2010, 93-99.

Horsley 2007

Leschhorn 1993

P. Herrmann, Inschriften von Sardeis, Chiron 23, 1993, 233-266.

G. R. H. Horsley, The Greek and Latin Inscriptions in the Burdur Archaeological Museum (RECAM 5), London 2007.

W. Leschhorn, Antike Ären: Zeitrechnung, Politik und Geschichte im Schwarzmeerraum und in Kleinasien nördlich des Tauros (Historia-Einzelschriften 81), Stuttgart 1993.

LGPN I

LGPN V.B.

P. M. Fraser - E. Matthews (eds.), A Lexicon of Greek Personal Names, Vol. I, The Aegean Islands, Cyprus, Cyrenaica, Oxford 1987.

J.- S. Balzat - R. W. V. Catling - É. Chiricat - F. Marchand - T. Corsten (eds.), A Lexicon of Greek Personal Names, Vol. V.B., Coastal Asia Minor: Caria to Cilicia, Oxford 2013.

Masson 1979

O. Masson, Cretica, BCH 103.1, 1979, 57-82.

Milet I.3

G. Kawerau - A. Rehm, Das Delphinion in Milet, Milet I.3, Berlin 1914.

Milner 1998

N. P. Milner, An Epigraphical Survey in the Kibyra-Olbasa Region, conducted by A. S. Hall (Regional Epigraphic Catalogues of Asia Minor III), Oxford 1998.

Pektaş 2013

K. Pektaş, Beçin Kalesi 2012 Yılı Kazı ve Onarım Çalışmaları, 35. Kazı Sonuçları Toplantıs1, 3. Cilt, 27-31 Mayıs 2013, 313-328.

Robert 1962

L. Robert, Villes d'Asie Mineure. Études de Géographie Ancienne, 2. Ed., Paris 1962.

SEG

Strubbe,

Arai Epitymbioi

Supplementum Epigraphicum Graecum

J. Strubbe, Arai Epitymbioi. Imprecations against Desecrators of the Grave in the Greek Epitaphs of Asia Minor. A Catalogue (IK 52), Bonn 1997.

Zgusta 1964

L. Zgusta, Kleinasiatische Personennamen, Prag 1964.

$\mathrm{ZPE}$

Zeitschrift für Papyrologie und Epigraphik 


\section{Karia ve Phrygia Bölgelerinden Bazı Yeni Yazıtlar}

Özet

Makalede 6 adet Yunanca yazıt tanıtılmaktadır. Bunlardan bir tanesi Karia Bölgesi’nde, Mylasa yakınındaki Beçin Kalesi’nde yürütülen kazılar sırasında ele geçen Hellenistik Dönem'e ait bir isim listesidir. Taşın üst kısmı hasarlı olduğundan, listenin tam olup olmadığını bilmek mümkün değildir. Yazıtın bir rahip ya da yönetici listesi olduğu düşünülebilir. Diğer beş yazıt ise Phrygia Bölgesi’nde, Antik devirde -şimdi kurumuş olan- Kazanes Nehri tarafından sulanan Acıpayam ovasında kopya edilmiştir. Bu buluntulardan biri adak, diğer dört tanesi ise mezar yazıtı olup, tümü Roma İmparatorluk Dönemi'ne tarihlenmektedir. Daha önce yayınlanmış olan mezar lanetlemesi (no. 4) dışındaki diğer beş yazıtın çevirisi şöyledir:

1. “Theoksenos'un oğlu Menippos, Apollonides'in oğlu Proteas, Dionysos'un oğlu Hippokrates, Polykritos'un oğlu Polites, Leon'un oğlu Antiokhos, Leon'un oğlu Melantas, Moas'in oğlu Zenon, Leon'un oğlu Lysimakhos, Iatrokles'in oğlu Phaidros, Iatrokles'in oğlu Eirenaios.”

2. "E... oğlu Poplis (bu mezarı) erkek kardeşi Menis'in anısı için (yaptırdı). Bu onurlandırma heykeli için 60 Denarius harcandi”.

3. “Monios oğlu Proteas bu adă̆ı (sundu)”.

5. "Zosimos kızı Artemeis (bu mezarı), çocukları Menis ve Menandros ile birlikte, Menis Arganios'un oğlu (olan) kocası Zosimos'un anısı için (yaptırdılar)”.

6. “Menandros ve Menis (bu mezarı) Artemeisia'nın anısı için (yaptırdılar)”.

Anahtar Kelimeler: Kazanes Vadisi, Mylasa, Eriza, Adak, Mezar Yazıtı, Mezar Lanetlemesi.

\section{Some New Greek Inscriptions from Caria and Phrygia}

\section{Abstract}

In the article six inscriptions are discussed. One of them (no. 1), a list of names from the Hellenistic period, was found at Beçin Kalesi near Mylasa. There is no indication about the nature of the list; it may be a record of names of some magistrates or priests. The rest of the inscriptions, all of which should date to the Roman imperial period, have been copied in Acıpayam Ovası which was watered by the Kazanes river in antiquity. One of these inscriptions (no. 3) is a dedication to an unknown god(dess), while the others are all funerary.

Keywords: Kazanes Valley, Mylasa, Eriza, Dedication, Funerary Inscription, Funerary Imprecation. 